УДК: 614.207:37.041:37.026

DOI:

Ольга Гуменюк, кандидат педагогічних наук, доцент кафедри стоматології дитячого віку Львівського національного медичного університету імені Данила Галищького проректор Львівського медичного інституту

Світлана Цюра, кандидат педагогічних наук, доиент кафедри загальної педагогіки та педагогіки вищої школи Львівського національного університету імені Івана Франка

Василь Гуменюк, кандидат педагогічних наук, доцент кафедри медицини катастроф і військової медицини Львівського національного медичного університету імені Данила Галищького

Оксана Сфремова, кандидат медичних наук, лікар-стоматолог приватного стоматологічного кабінету

\title{
ДИДАКТИЧНИЙ ПОТЕНЦАЛ ПЕРСОНАЛЬНОГО ОСВІТНЬОГО ПРОСТОРУ В ФОРМУВАННІ ДОСВІДУ ПРОФЕСІЙНОЇ МОБІЛЬНОСТІ МАЙБУТНІХ МЕДИЧНИХ СЕСТЕР
}

Акцентовано на актуальності формування досвіду професійної мобільності майбутніх медсестер за напрямами особистісної та горизонтальної мобільності. Проаналізовано характеристики персонального освітнього простору студента у контексті специфіки медичної освіти. Виокремлено компоненти дидактичного потенціалу персонального освітнього простору: технологічний, змістовий, діяльнісний, оціннорезультативний, соиіальний; розглянуто можливості його використання для формування досвіду особистої та горизонтальної професійної мобільності майбутніх медсестер.

Ключові слова: майбутні медичні сестри; професійна мобільність; персональний освітній простір; медична освіта.

תim. 6.

Olha Humenyuk, Ph.D.(Pedagogy), Associate Professor of the Childhood Dentistry Department Lviv Danylo Halytskiy National Medical University Vice-Rector of Lviv Medical Institute Svitlana Tsyura, Ph.D.(Pedagogy), Associate Professor of the Common Pedagogics and Pedagogics of High School Department Lviv Ivan Franko National University Vasyl Humenyuk, Ph.D.(Pedagogy), Associate Professor of the Catastrophe Medicine and Military Medicine Department Lviv Danylo Halytskiy National Medical University Oksana Yefremova, Ph.D.(Medical Sciences), Dentist of private practice

\section{DYDACTIC POTENTIALITY OFTHE PERSONAL EDUCATIONAL ENVIRONMENT IN THE DEVELOPMENT OF PROFESSIONAL MOBILITY OF FUTURE NURSES}

The article is highlights that in in Ukrainian High Medical Schools as well in the process of development of professional mobility of nurses aren't introduced the procedures of international mobility of students. The authors generalized, that an absence of possibilities for international mobility of medical students is based on: differences of educational curriculum programs in Ukraine and European Union; on high cost of the medical education; programs are focused on postgraduate education level. The directions of experience development of nurses are defined: personal professional mobility, faced on improving of professionally-oriented personal qualities, cognitive, communicative, social, creative potentiality; horizontal mobility - spread of opportunities in additional branches of activity or in other professional displays. The characteristics of personal educational environment are presented as: a complex of information and resources, that is formed by the person and appeared around him, it is accessible for him in present timeor is stored by him in the net; content-instrumental, mainly self-organizing actions and procedures, which are based on necessities of self-informing, self-development, self-control; process-content, organizationally-pedagogical and self-organizing complex, which is formed by personal educational net, personal educational content, personal educational environment.

In the article the features of filling the personal educational environment in the conditions of obtaining modern medical education are analyzed. It separated the components of didactic potentiality of personal educational environment; technologic, a content (educational platforms, an educational and communicative informational resources, medical informational materials of the net), activity, evaluatively-resultive, social, and it was discussed 


\section{ДИДАКТИЧНИЙПОТЕНЦІАЛПЕРСОНАЛЬНОГООСВІТНЬОГОПРОСТОРУ В ФОРМУВАННІ ДОСВІДУ ПРОФЕСІЙНОӤ МОБЛЬНОСТІ МАЙБУТНІХ МЕДИЧНИХ СЕСТЕР}

opportunities of its using in the direction of formation of the experience of personal and horizontal professional mobility of future nurses.

It was concluded that in the condition of absence of international mobility of future nurses on the level of graduating higher education the development of experience of personal professional and horizontal mobility is maintained by functioning of the personal educational environment of the student, resources of which is better to use more actively in the direction of organization of educational process.

Keywords: future nurses; professional mobility; personal educational environment; medical education.

П остановка проблеми. Темпи економічного та інформаційного розвитку в сучасному глобальному просторі постійно зростають. У стислі терміни у різних галузях знань виникає потреба впровадження нових технологій, повної або часткової перекваліфікації працівників. Перманентний перерозподіл ваги й функціонального призначення або навіть втрата чинних та виникнення нових професійних сегментів на ринку праці ставить професіонала в умови, які диктують необхідність навчання впродовж життя, а отже, опираються на його психологічну готовність та особистий досвід професійної мобільності.

Розвиток ринкових відносин в Україні та їі входження на міжнародний ринок праці й капіталу ставить працездатне населення в умови готовності до змін у професійній сфері, до змін сфери діяльності, місця праці. Якщо в умовах перших років пострадянського простору така необхідність гостро постала лише перед молодим поколінням випускників, що втратили гарантії працевлаштування після закінчення професійної освіти та фахівців низки науково-дослідних установ, то на кінець другого десятиліття XXI століття професійна мобільність стає звичним явищем соціоекономічного простору.

В умовах постіндустріального, інформаційного глобалізованого середовища різних країн відбувся перехід від пріоритету монопрофесіоналізму й орієнтації активного населення на тривалу вузьку спеціалізацію - як гарантію успішного кар'єрного росту, до полі професіоналізму, тобто готовності до перекваліфікації, перепрофілювання, не з причин гострої соціальної та економічної необхідності, а 3 мотивів самоактуалізації, потреби у розвитку.

Професійна мобільність фахівців, що отримали медсестринськуосвіту відрізняється від мобільності майбутніх медичних сестер. Готовність майбугніх медсестер, що навчаються у закладах вищої медичної освіти за освітніми програмами бакалавра та магістра, до розвитку у професійній сфері має низку особливостей вияву мобільності за визначеними науковцями типами та напрямами.

Найбільш ефективними з програм міжнародної академічної мобільності у другому десятилітті XXI століття виявилися: проекти обміну, фінансовані Свропейським Союзом (Еразмус+), студентів бакалаврату, магістеріуму i PhD студентів/аспірантів; програми мобільності за двосторонніми договорами між спеціалізованими кафедрами, факультетами, університетами, країнами; програми подвійних дипломів та спільні програми університетів кількох країн. На 2019 2020 роки американські університети запропонували розгалужену Програму обміну для студентів бакалаврату закладів вищої освіти (Global Undergraduate Exchange Program), основними акцентами якої $€$ формування лідерських умінь, соціальної відповідальності, культурного діалогу. Всі ці програми та їх попередники не стосуються медичної освіти.

Для студентів вищих медичних закладів освіти діють програми, орієнтовані на післядипломну освіту, спеціалізації: постійна програма професійних обмінів Міжнародної федерації асоиіацій студентів медиків (International Federation of Medical Students Assosiations (FMSA); програма European Medical Students' Association (EMSA). Ïх основним завданням $\epsilon$ реалізація академічної мобільності студентівмедиків, що мають бажання поглибити спеціалізацію, здобути нову медичну або дотичну до медичної спеціалізацію. Для розвитку міжнародної мобільності українських студентів медиків, у тому числі й медичних сестер, закладами освіти України укладаються двосторонні програми обміну студентами 3 закордонними вищими медичними школами, здебільшого під час проходження практик.

Документом, який регулює реалізацію права на академічну мобільність для українських i міжнародних учасників освітнього процесу в Україні стала Постанова Кабінету Міністрів України “Про затвердження Положення про порядок реалізації права на академічну мобільність" (2015) [4,3]. Визначено, що формами академічної мобільності $\epsilon$ : навчання за програмами академічної мобільності, мовне та наукове стажування; участь у спільних проектах, викладання, наукове дослідження, наукове стажування, підвищення кваліфікації. У Положенні уточнено, що організаційні умови академічної мобільності укладаються та встановлюються іiі учасниками [4]. 


\section{ДИДАКТИЧНИЙПОТЕНЦАЛПЕРСОНАЛЬНОГООСВІТНЬОГО ПРОСТОРУ В ФОРМУВАННІ ДОСВІДУ ПРОФЕСІЙНОӤ МОБЛЬНОСТІ МАЙБУТНІХ МЕДИЧНИХ СЕСТЕР}

Аналіз основних досліджень і публікацій. До питання професійної мобільності у загальному контексті завдань соціальної мобільності дослідники звернулися у другій половині ХХ століття. Прикладом дослідження й наукового трактування співвідношення освіти та мобільності стала робота Шейли Фіцпатрик (Sheila Fitzpatrisk) "Освіта та соціальна мобільність у Радянському Союзі 1921 - 1934 рр. (Кембриджські, радянські та пострадянські дослідження)" [5]. Базові основи професійної мобільності як складової суспільних процесів і однієї із характеристик глобалізованого світу було викладено у працях Б. Барбера (B. Barber), Ю. Веніга (J. Wenig), Е. Гідденса (A. Giddens). У кінці XX століття американські дослідники Р. Гаусер, Д. Феатгерман (R. Hauser, D. Featherman) схарактеризували загальну тенденцію до зменшення тривалості циклу зміни людиною професії - встановивши частоту 2 - 3 цикли протягом життя [3].

Серед сучасних українських дослідників професійна мобільність фахівців стала предметом дослідження О. Цись, що охарактеризував іï як науково-педагогічну категорію [6], Т. Прохоренко (професійна мобільність як фактор професійної успішності), Л. Сушенцевої (як сучасна педагогічна проблема), Н. Сургунд (як складова системи професійного розвитку сучасного фахівця) та інших; формування професійної мобільності майбутніх економістів у процесі навчання у вищих закладах освіти стало предметом дисертаційного дослідження Є. Іванченко [2].

Професійну мобільність медичних сестер як фактор їх успішної професійної діяльності розглянуто у публікаціях Ю. Дзвінчук (виявлено, що у досліджуваній групі (140 медсестер) переважає середній рівень професійної мобільності, з'ясовано, що зі “збільшенням трудового стажу рівень знижується”, “високий рівень притаманний фахівцям із стажем роботи 1 - 5 та $6-14$ років") [1, 51].

Таким чином, на відміну від налагоджених університетами України програм академічної мобільності студентів немедичних спеціальностей, питання розвитку досвіду академічної й професійної мобільності майбутніх медичних сестер залишається актуальним, практично не вирішеним, а також порівняно мало дослідженим в науково-педагогічних джерелах.

Мета статті. Аналіз дидактичного потенціалу персонального освітнього простору в процесі формування досвіду професійної мобільності майбутніх медичних сестер.

Виклад основного матеріалу дослідження. Питання про формування досвіду професійної мобільності майбутніх медичних сестер доцільно розглянути після уточнення поняттєвого апарату. Серед категорій, які використовуються у наукових джерелах розрізняють поняття “соціальна мобільність”, “професійна мобільність”, “академічна мобільність”, “освітня мобільність”. Аналіз джерел виявив трактування поняття “професійна мобільність" у публікаціях А. Ващенко, Л. Горюнової, Ю. Дзвінчук, Е. Зеєр, Н. Кожемякіної, Є. Іванченко, М. Лошкарьова, I. Шпакіної та ін. Узагальнюючи погляди науковців відмітимо, що поняття “професійна мобільність" розглядається ними у декількох напрямах, як от:

- психологічна готовність особистості швидко, гнучко й ефективно опановувати нові професійні знання, уміння, технології;

- психологічна активність, динаміка розвитку власних ресурсів від особистісних якостей до інформаційних та матеріальних, з метою адаптації до змін;

- освоєння сфери професійної діяльності, професійний розвиток, ініціативи та реалізація потреб кар'єрного росту, професійної переорієнтації, спеціалізації, підвищення і зміни кваліфікації тощо;

- процес самореалізації людини у професійній сфері, динамічні зміни внесені нею у професійне середовище і власну Я-концепцію.

Розрізняють також горизонтальну мобільність - розширення своїх можливостей в суміжних галузях діяльності або переорієнтацію спрямованості на іншу професійну сферу; вертикальну - розширення й поглиблення своїх функцій в обраному напрямі діяльності; особистісну - розширення своїх професійно орієнтованих особистісних якостей, когнітивного, комунікативного, соціального, творчого потенціалу.

Відсутність можливостей для міжнародної мобільності українських студентів-медиків зумовлена насамперед відмінностями програм професійної підготовки студентів в Україні та в університетах Європейського Союзу та Північної Америки, високою вартістю медичної освіти та орієнтованістю програм мобільності на післядипломну освіту й медичні спеціалізації, можливості яких в країнах 3 розвиненою економікою значно вищі. Водночас завданням професійної підготовки фахівців у сучасному закладі освіти є формування інтегративної характеристики особистості - готовності та здатності до гнучкого й активного реагування на зміни у професійній сфері.

Акцентуємо увагу на особливостях розвитку професійної мобільності майбутніх медичних 


\section{ДИДАКТИЧНИЙПОТЕНЦАЛПЕРСОНАЛЬНОГООСВІТНЬОГО ПРОСТОРУ В ФОРМУВАННІ ДОСВІДУ ПРОФЕСІЙНОЇ МОБІЛЬНОСТІ МАЙБУТНІХ МЕДИЧНИХ СЕСТЕР}

сестер за двома напрямами: формування досвіду особистісної професійної мобільності, яка спрямована на розширення своїх професійно орієнтованих особистісних якостей, когнітивного, комунікативного, соціального, творчого потенціалу, та горизонтальної мобільності.

Відповідно до мети статті, зосередимо увагу на встановленні дидактичного потенціалу персонального освітнього простору в процесі формування досвіду особистої та горизонтальної професійної мобільності майбутніх медичних сестер. Для цього, насамперед, розглянемо поняття персональний освітній простір.

Порівняно нове у педагогічних джерелах явище і поняття персональний освітній простір (personal learning environment) використовується для характеристики:

- комплексу інформації та ресурсів, який утворений особою і виник навколо неї, доступний ій в актуальному часі, або збережений нею у мережі;

- змістово-інструментальних, здебільшого самоорганізовуваних дій та процедур, що зумовлені потребами самоінформування, саморозвитку, самоконтролю;

- процесуального-змістового, організаційнопедагогічного і самоорганізовуваного комплексу, що його утворюють персональна навчальна мережа, персональний навчальний зміст, персональне навчальне середовище. Додатково уточнимо, що персональна навчальна мережа, це своєрідний масив сучасних різновидів форм $\mathrm{i}$ методів учіння - програми та соціальні інформаційні ресурси, що дають можливість майбутньому фахівцеві самостійно, або за участі викладача, організувати свою пізнавальну діяльність. Персональну навчальну мережу утворює особа, що використовує: інструменти та прилади, комп'ютерне програмне забезпечення; соціальні мережі, форуми, можливості інтерактивного спілкування, сервіси, освітні портали, дистанційні курси, пошукові системи, електронну пошту, хмарні технології. Персональний навчальний зміст - інформація та матеріали, розміщені у мережі та накопичені користувачем. Персональне навчальне середовище - мережа взаємодії, створена студентом $з$ власної ініціативи, за участю інших, за допомогою інформаційних сервісів, соціальних мереж, навчальних ресурсів, що дає їй відповіді на поставлені нею ж питання у напрямі розвитку й самоосвіти. Взаємодія із цим середовищем дає можливість майбутньому фахівцеві створити основні компоненти своєї персональної мережі змістово-процесуальні кластери.
Аналізуючи особливості утворення i наповнення персонального освітнього простору закладу медичної освіти у цілому й щодо підготовки майбутніх медичних сестер зокрема, було виокремлено наступні компоненти його дидактичного потенціалу.

1. Технологічний потенціал персонального освітнього простору майбутніх медсестер. На відміну від професійної підготовки бакалаврів гуманітарного у цілому та природничо-наукового профілів навчання медичних сестер має технологічну спрямованість. Зміст освіти містить навчальні завдання 3 вироблення професійних вмінь, доведення техніки їх виконання до досконалості та автоматизму. Вміння традиційно формують на практичних заняттях 3 використанням муляжів, фантомів, пацієнтів під час практики. Сучасна інформаційна мережа пропонує широкий спектр професійних, що продемонстрованих фахівцями та безпосередньо створених навчальних відеозаписів, фахових та любительських тренінгів, майстер-класів, навчальних фільмів. Їх перегляд та опрацювання дають можливість майбутньому медику у навчальний або позанавчальний час додатково детально розглянути й опрацювати покрокову процедуру та маніпуляції, які виконує медична сестра. Наведемо кілька прикладів таких україномовних матеріалів за першим посиланням на pecypci www.youtube.com - “Алгоритм виконання внутрішньом'язевої ін'єкції” (https:// www.youtube.com/watch?v=GS-8Upa0LYg); “Навчальний фільм. Догляд за хворими. Основи медсестринської справи для студентів навчальних медичних закладів I-IV рівнів акредитаціï'. (https:/ /www.youtube.com/watch?v=Gob7HI7W04U).

2. Змістовий потенціал персонального освітнього простору майбутніх медсестер. Основною формою навчання студента у вищій школі є самостійна робота. Покоління, яке приходить у заклад вищої освіти набагато більш охоче користується для пошуку інформації електронними ресурсами та електронними бібліотеками. Наведемо перелік основних електронних ресурсів, що розширюють інформаційний потенціал лекцій, практичних занять, друкованих матеріалів бібліотек.

1. Освітні платформи. INgenius українська освітня платформа для студентів вищих медичних закладів освіти та медичних працівників - містить матеріали про медичні дослідження, проекти, гранти, матеріали, посилання на англомовні сайти та ресурси. Prometheus - українська освітня платформа, що пропонує безкоштовні онлайн-курси, які 
дозволяють отримати сертифікат з різних галузей, лекції ведуть викладачі закладів вищої освіти, керівники компаній. Для студентів-медиків Prometheus пропонує безкоштовні курси "Проста гістологія”, “Вступ до кардіології, “Оцінка функції зовнішнього дихання в пульмонологічній та терапевтичній практиці”. Англомовна освітня платформа Coursera - найбільш популярний у світі освітній ресурс з онлайн-курсами, який має платформу медико-біологічних наук. Лекції читають відомі викладачі та професіонали світових університетів, лідерів у своїй галузі. Курси безкоштовні, однак сертифікат платний.

2. Освітньо-комунікативні інформаційні ресурси. Для медиків-початківців працює популярний British Medical Journal (https://goo.gl/ VevtBE), який пропонує безкоштовний доступ до двох своїх освітніх ресурсів - BMJ Best Practice та BMJ Learning. Medscape. Спеціалізовані інформаційні ресурси News Medical та Medscape - 3 медичними новинами, науковими публікаціями 3 результатами досліджень, повідомленнями про нові відкриття, довідковими та дидактичними (тренувальними) матеріалами.

3. Інформаційні матеріали тематично, відповідно до галузі, або випадковим чином згруповані на Youtube, Medtube - медичні відео, зображення, зразки документів. Epocrates - широкий інформаційний ресурс, що містить інформацію про нозології, ліки, клінічні поради. До послуг користувача мережі медичні та фармацевтичні енциклопедії, текстові та такі, що мають ілюстрації та фотографії, серед них: сайт A.D.A.M. Medical Encyclopedia, яка включає понад 4000 статей про хвороби, їх симптоми, лікування, профілактику захворювань; Innerbody - сайт 3 детальними анатомічними моделями людського тіла, який дозволяє не лише вивчити будову тіла і його частин, але й засвоїти назви систем та органів англійською мовою. Для вивчення міжнародної медичної термінології у мережі є словник медичних термінів MediLexicon (понад 10000 слів).

3. Діяльнісний потенціал персонального освітнього простору майбутніх медсестер. У контексті розвитку досвідупрофесійної мобільності майбутніх медсестер саме персональний освітній простір дає особі відкриту сферу можливостей для формування готовності та здатності до гнучкого й активного реагування на зміни упрофесійній сфері. Доступність інформації про зміни на ринку праці, вимоги до працівників у тій чи іншій сфері тощо стають доступними студенту, ще до того, ніж він потрапляє у заклад для проходження практики чи стажування.
4. Оцінно-результативний потенціал персонального освітнього простору майбутніх медсестер. На відміну від інших компонентів вже має широке розповсюдження серед українських студентів-медиків. Це тестові завдання різного рівня складності, матеріали ліцензійних іспитів “Крок 1”, “Крок 2”, міжнародні ліцензійні іспити, що дають право претендувати на отримання ліцензії в іншій країні. Студент за власної ініціативи має можливість перевірять якість своєї підготовки як завгодно часто, безкоштовно, користуючись матеріалами тестувань забагато років, які є у вільному доступі.

5. Соціальний потенціал персонального освітнього простору майбутніх медсестер. Важливими для сучасного простору університетської освіти $€$ питання соціальної місії університетів та формування соціально відповідального фахівця, професіонала, людини здатної брати на себе відповідальність за суспільно значущі зміни у сферах, дотичних до професійної. Мережа забезпечує для студента можливість поінформування про соціальні проекти молоді у різних країнах, навчальних закладах, дозволяє синхронізувати громадську активність у різних професійних сферах, можливості фахівців різного рівня. Так, проекти, ініційовані студентами, які спрямовані на соціальну підтримку хворих та осіб з інвалідністю отримують значне розширення сфери прикладення допомоги, якщо ії̈ надають й майбутні медики. Екологічні заходи, здоров'язбережувальні технології та ініціативи 3 їх впровадження дозволяють переорієнтуватися тим студентам, які вирішують працювати у сферах дієтичного харчування, косметичної медицини, реабілітології тощо.

Ще одним із напрямів розвитку професійної мобільності, як особистої, так і горизонтальної, $\epsilon$ наявність широкого спектра ресурсів, що включають студента в міжнародне англомовне медичне середовище. Це: Sermo - соціальна мережа, створена спеціально для медичної спільноти, де можна розповісти про свій досвід та дізнатися, як працюють медичні працівники інших країн; Oxford English for Careers (Nursing 1 і 2 для медсестер/медбратів) серія матеріалів, що містить вправи на вивчення граматики, розвиток словникового запасу та слухання для тих, хто хоче вдосконалити професійну англійську; Hospital English - відео та аудіофайли про техніки та навчальні матеріали щодо лікування, характеристики медикаментів, лікувальні процедури тощо.

Висновки і перспективи подальших розвідок у даному напрямку. Таким чином, за 
умови відсутності міжнародної мобільності майбутніх медичних сестер на рівні додипломної освіти, формування досвіду особистої професійної та горизонтальної мобільності забезпечується функціонування персонального освітнього простору, можливості якого доцільно використовувати в організації навчального процесу. Узагальнено особливості утворення і наповнення персонального освітнього простору в умовах отримання студентом сучасної медичної освіти. Виокремлено компоненти дидактичного потенціалу персонального освітнього простору в процесі формування досвіду професійної мобільності майбутніх медичних сестер: технологічний, змістовий, діяльнісний, оціннорезультативний, соціальний та розглянуто можливості його використання у напрямі формування досвіду особистої та горизонтальної професійної мобільності майбутніх медсестер. Подальшого дослідження потребують ті напрями організації освітнього процесу у вищій школі, які забезпечать більш системне використання персонального освітнього простору у напрямі розвитку професійної мобільності майбутніх медсестер.

\section{ЛІТЕРАТУРА}

1. Дзвінчук Ю.В. Професійна мобільність медичних сестер як фактор їх успішної професійної діяльності. Психологія : реальність $i$ перспективи. Зб. наук. праџь РДГУ. 2016. Вип. 6. С. $48-52$.

2. Іванченко С.А. Формування професійної мобільності майбутніх економістів у процесі навчання у вищих навчальних закладах: дис. канд.пед.наук: 13.00.04. Одеса, 2005. 181 с.

3. Hauser R.M., Featherman D.L. The process of stratification: Trends and analisis. New York: Akademic press, 1977. 287 p.

4. Постанова Кабінету Міністрів України “Про затвердження Положення про порядок реалізації права на академічну мобільність” № 579 від 12 серпня 2015 року. URL: http://www.kmu.gov.ua/ control/uk/cardnpd?docid=248409199.
5. Fitzpatrisk Sh. Education and Social Mobility in the Soviet Union 1921-1934. Cambridge University Press. 1979. 347 p.

6. Цись О. Професійна мобільність майбутнього фахівця як науково-педагогічна категорія. Освіта дорослих : теорія, досвід, перспективи. 2013. Вип. 7. С. 249-256.

\section{REFERENCES}

1. Dzvinchuk, Yu.V. (2016). Profesiyna mobilnist' medychnykh sester yak faktor yikh uspishnoyi profesiynoyi diyalnosti [Professional mobility of nurses as a factor of their successful professional activity]. Psychology: reality and perspectives. Collection of scientific papers of RDHU. Issue 6. pp. 48-52. [in Ukrainian].

2. Ivanchenko, Ye.A. (2005). Formuvannya profesiynoyi mobilnosti maibutnikh ekonomistiv u protsesi navchannya u vyshchykh navchalnykh zakladakh [Development of professional mobility of future economists in the process of study in Higher educational institutions]. Candidate's thesis. Odesa, 181 p. [in Ukrainian].

3. Hauser, R. M. \& Featherman, D. L. (1977). The process of stratification: Trends and analisis. New York: Akademic press, 287 p. [in English].

4. Postanova Kabinetu Ministriv Ukrayiny "Pro zatverdzhennia Polozhennia pro poriadok realizatsiyi prava na akademichnu mobilnist” № 579 vid 12 serpnia 2015 roku [Legislative act of Cabinet of Ministers of Ukraine "About ratification of the Statement about implementation of the right on academic mobility” № 579, August, 12, 2015). Available at: http://www.kmu.gov.ua/control/uk/ cardnpd?docid=248409199. [in Ukrainian].

5. Fitzpatrisk, Sh. Education and Social Mobility in the Soviet Union 1921-1934. Cambridge University Press. 1979. 347 p. [in English].

6. Tsys, O. (2013). Profesiyna mobilnist maibutnioho fakhivtsia yak naukovo-pedahohichna katehoriya [Professional mobility of a future specialist as scientifically-pedagogical category]. Education of adults: theory, experience, prospects. Issue 7, pp. 249-256. [in Ukrainian].

Стаття надійшла до редакції 22.04.2019

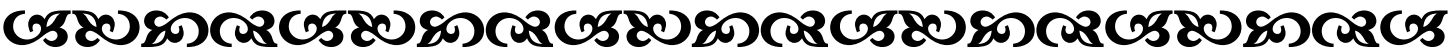

\author{
"Коли вам здається, що ціль недосяжна, не змінюйте мету - змінюйте свій план \\ diü". \\ Конбууиіü \\ давньокитайський білособб
}

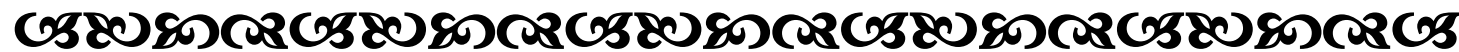

